\title{
EL APORTE DE LOS INSTRUMENTOS INTERNACIONALES Y DE LA NORMATIVA VOLUNTARIA. LA FORMACIÓN UNIVERSITARIA EN EDUCACIÓN AMBIENTAL EN LAS INGENIERÍAS EN ARGENTINA
}

\section{CONTRIBUTION OF INTERNATIONAL INSTRUMENTS AND VOLUNTARY REGULATIONS: UNIVERSITY TRAINING IN ENVIRONMENTAL EDUCATION IN ENGINEERING BRANCHES IN ARGENTINA}

\author{
Clara M. Minaverry ${ }^{1^{*}}$, Teresa Gally ${ }^{2}$
}

\begin{abstract}
${ }^{1}$ Instituto de Investigaciones Jurídicas y Sociales Ambrosio Lucas Gioja, Facultad de Derecho, Universidad de Buenos Aires. (cminaverry@derecho.uba.ar). ${ }^{2}$ Departamento de Tecnología, Universidad Nacional de Luján. Ingeniera Agrónoma (Universidad de Buenos Aires), Especialista en ingeniería en calidad (Universidad Tecnológica Nacional) (teresagally@hotmail. com)
\end{abstract}

\section{RESUMEN}

El objetivo de este trabajo es exponer los aspectos centrales descriptos por una selección de instrumentos internacionales, cuyos contenidos justifican la incorporación de la "educación ambiental” en los programas de las diferentes carreras universitarias, en especial en las vinculadas con el ámbito productivo, como es el caso de las ingenierías. Nuestra hipótesis de trabajo se basa en que todos los conceptos que se derivan de dichos instrumentos (sobre sostenibilidad, producción limpia y educación ambiental) son fundamentales para lograr una formación integral de los profesionales. En este sentido, los egresados de carreras universitarias y de posgrado que se vinculan con estas áreas habitualmente se encuentran a cargo de implementar una serie de procesos productivos, cuya ejecución involucra diversas decisiones en relación con la aplicación de prácticas sostenibles o no sostenibles. Se trata de una investigación de carácter exploratorio; su estructura es de tipo bibliográfico-documental y descriptiva, y la metodología utilizada es cualitativa. Como técnica de análisis se utiliza a la hermenéutica de textos normativos y de documentos públicos. A modo de conclusión se considera fundamental conocer las normas voluntarias sobre reponsabilidad social, ya que estas pueden cubrir algunas lagunas jurídicas, o bien, complementar las normativas vigentes.

Palabras clave: derecho internacional, producción, responsabilidad social, sostenibilidad, universidad.

\footnotetext{
* Autor responsable $*$ Author for correspondence.

Recibido: diciembre, 2015. Aprobado: abril, 2017.

Publicado como ARTÍCULO en ASyD 15: 173-190. 2018.
}

\begin{abstract}
The objective of this study is to expose the central aspects described by a selection of international instruments, whose contents justify the incorporation of "environmental education" in programs of different university careers, especially in those linked to the productive scope, as is the case of engineering branches. Our working hypothesis is based on the fact that all the concepts that derive from such instruments (about sustainability, clean production and environmental education) are fundamental to achieve an integral training of professionals. In this sense, those that graduate from university careers and graduate studies that are linked to these areas are habitually in charge of implementing a series of productive processes, whose execution involves different decisions in relation to the application of sustainable or non-sustainable practices. This is a study of an exploratory nature; its structure is biological-documental and descriptive, and the methodology used is qualitative. The hermeneutics of normative texts and public documents is used as analysis technique. As conclusion, it is considered to be fundamental to understand the voluntary norms on social responsibility, since these can cover some legal lapses, or else, complement the current regulations.
\end{abstract}

Key words: international law, production, social responsibility, sustainability, university.

\section{INTRODUCTION}

$\mathrm{S}$ ince the decade of the 1970s, we have observed that treatment of the environmental problematic was installed in the international 


\section{INTRODUCCIÓN}

$\mathrm{A}$ partir de la década de los setenta se observa que el tratamiento de la problemática ambiental se instaló en la agenda internacional, pero que fue atendida enfocándose en virtud de dos procesos íntimamente vinculados: el creciente deterioro y agotamiento de los recursos naturales y la expansión de los conflictos socio-ambientales.

En este contexto, en la Conferencia de Naciones Unidas de Medio Ambiente Humano celebrada en Estocolmo en 1972, se observó que la cuestión ambiental en los ámbitos políticos mundiales cobró envergadura y se institucionalizó. El fenómeno indiscutible e inevitable de la globalización favoreció que se logre un mayor entendimiento de los conflictos ambientales, como ocurre con el cambio climático, en tanto que el Protocolo de Kyoto establece el principio de "responsabilidades comunes, pero diferenciadas" para los diferentes países del mundo. Por tal razón, se comenzó a promover que los dirigentes de todos los países del mundo se reúnan para negociar, fijar condiciones y entre todos mejorar la situación económica, ambiental y social mundial, y tender a equilibrar relativamente a todos los países del mundo (Minaverry, 2013).

Al finalizar el siglo XX y al comienzo del siglo XXI, la "cuestión ambiental" dio lugar al desarrollo de las siguientes conferencias de Naciones Unidas: la de Río de Janeiro de 1992, donde las Naciones Unidas sobre Ambiente y Desarrollo (CNUAD) acordaron La Declaración de Río; la Cumbre Mundial sobre el Desarrollo Sostenible de Johannesburgo de 2002, donde se firmó el Plan de acción y la Declaración Política de Johannesburgo sobre el Desarrollo Sustentable; y, más recientemente, la Conferencia de las Naciones Unidas sobre el Desarrollo Sostenible «Rio+20» celebrada en 2012, donde se acordó la Resolución 66/288 El futuro que queremos. De esta manera, estos acuerdos internacionales han comprometido esfuerzos por parte de los Estados firmantes tendientes a proteger el ambiente, mitigar los impactos o remediar el daño causado mediante la sanción de normas jurídicas.

A la par de los eventos citados, en Argentina se ha ido conformando y consolidando el derecho ambiental como disciplina autónoma e independiete de otras ramas jurídicas, y que "tiene por objeto el estudio de las relaciones del hombre con la naturaleza, agenda, although it was addressed by focusing in virtue of two processes that are intimately linked: the growing deterioration and exhaustion of natural resources, and the expansion of socio-environmental conflicts.

Within this context, at the United Nations Conference on the Human Environment celebrated in Stockholm in 1972, it was observed that the environmental issue took on importance and became institutionalized in global political spheres. The undeniable and unavoidable phenomenon of globalization favored for there to be a greater understanding of environmental conflicts, as is the case with climate change, while the Kyoto Protocol established the principle of "common responsibilities, although differentiated" for the different countries of the world. For this reason, it was fostered for leaders of all countries of the world to meet, to set conditions, and among all to improve the global economic, environmental and social situation, tending to balance all countries in the world relatively (Minaverry, 2013).

At the end of the $20^{\text {th }}$ century, and at the beginning of the $21^{\text {st }}$ century, the "environmental issue" gave place to the development of the following United Nations conferences: Rio de Janeiro in 1992, where the United Nations Conference on Environment and Development (UNCED) agreed upon the Rio Declaration; the Johannesburg Earth Summit on Sustainable Development in 2002, where the Action Plan and the Johannesburg Declaration on Sustainable Development were signed; and, more recently, the United Nations Conference on Sustainable Development "Rio+20" celebrated in 2012, where Resolution 66/288 was signed, The future we want. In this way, these international agreements have committed efforts from the signing States that tend to protect the environment, mitigate the impacts and/ or remedy the damage caused through the sanction of legal norms.

Along with the events mentioned, environmental law has been shaped and consolidated in Argentina as an autonomous discipline, independent of other legal branches, and which "has the aim of studying the relationships of man with nature, insofar as it allows establishing this relationship clearly in the action of man on the environment, in terms of his anthropic activities of modification of his environment in the interest of satisfying his own needs for food, housing 
en la medida que permita establecer con claridad esa relación en la actuación del hombre sobre el medio ambiente, en cuanto a sus actividades antrópicas de modificación de su entorno en aras de la satisfacción de necesidades propias de alimentación, vivienda y desarrollo" (Pigretti, 2000). Esta definición claramente posee un enfoque antropocéntrico en tanto un bien vale en la medida que sirva al hombre, sin reconocer un valor de "no uso" (Laterra et al., 2011). Esta concepción ya fue superada por otras que visualizan a los ecosistemas en su conjunto y no únicamente con el objetivo de suministrar beneficios a los seres humanos a través de la mera utilización de sus recursos naturales. Actualmente se tiende a implementar una protección jurídica ambiental sistémica e integral, como es el caso del reconocimiento de la existencia de los servicios ambientales en la ley nacional de presupuestos mínimos para la protección de los bosques nativos $\mathrm{N}^{\circ} 26.331$ de Argentina.

A nivel local, la consagración constitucional del paradigma ambiental en 1994 consolidó el "desarrollo sostenible" como uno de sus principios básicos y acordó la obligación de dictar la normativa necesaria para la protección de los recursos naturales. El primer párrafo del artículo 41 de la Constitución Nacional de Argentina establece lo siguiente:

"Todos los habitantes gozan del derecho a un ambiente sano, equilibrado, apto para el desarrollo humano y para que las actividades productivas satisfagan las necesidades presentes sin comprometer las de las generaciones futuras, y tienen el deber de preservarlo. El daño ambiental generará prioritariamente la obligación de recomponer, según lo establezca la ley."

Por su parte, la Educación Ambiental puede definirse como la reorientación y articulación de las diversas disciplinas y experiencias educativas que facilitan la percepción integrada del ambiente, haciendo posible una acción más racional y capaz de responder a las necesidades sociales. Tiene como objetivo principal transmitir conocimientos, formar valores, y desarrollar competencias y comportamientos que puedan favorecer la comprensión y la solución de los problemas ambientales (Giuffré, 2004).

La educación ambiental ya fue reconocida e incorporada en diversos ordenamientos jurídicos locales, como es el caso del artículo $200^{3}$ de la Constitución de la Provincia de Buenos Aires en los artículos 14 y 15 de la ley general del ambiente $N^{\circ} 25.676^{4}$, y and development" (Pigretti, 2000). This definition clearly poses an anthropocentric approach while a good is worth insomuch as it serves man, without recognizing a value of "non-use" (Laterra et al., 2011). This conception has already been surpassed by others that visualize ecosystems as a whole and not just with the aim of providing benefits to human beings through the mere use of their natural resources. Currently, there is a tendency to implement a systemic and integral environmental legal protection, as is the case of the recognition of the existence of environmental services in the national law of minimal budgets for the protection of native forests $\mathrm{N}^{\circ} 26.331$ of Argentina.

At the local level, the constitutional recognition of the environmental paradigm in 1994 consolidated "sustainable development" as one of its basic principles and agreed upon the obligation of passing the necessary laws for the protection of natural resources. The first paragraph of Article 41 of Argentina's National Constitution establishes the following:

"All inhabitants have the right to a healthy, balanced environment, apt for human development and for productive activities to satisfy the needs present without compromising those of future generations, and have the duty to preserve it. Environmental damage will generate principally the obligation of repairing, according to law."

In turn, Environmental Education can be defined as the redirection and articulation of various educational disciplines and experiences that ease the integrated perception of the environment, making a more rational action possible and capable of responding to social needs. It has the main objective of transmitting knowledge, forming values, and developing competencies and behaviors that can favor the understanding and solution of environmental problems (Giuffré, 2004).

Environmental education has already been recognized and integrated into various local legal regulations, as is the case of article $200^{3}$ of the Constitution of the Province of Buenos Aires, in articles 14 and 15 of the general environmental law $\mathrm{N}^{\circ} 25.676^{4}$, and in article 5 of the integral law of the environment in the Province of Buenos Aires $\mathrm{N}^{\circ}$ $11.723^{5}$.

Likewise, the contribution of Social Responsibility implies the continuous commitment 
en el artículo 5 de la ley integral del medioambiente de la Provincia de Buenos Aires No $11.723^{5}$.

Asimismo, el aporte de la Responsabilidad Social implica el compromiso continuo de una organización de comportarse de manera ética, y de colaborar con el desarrollo económico y con la mejora de la calidad de vida de la comunidad. Asimismo intenta asegurar que todas las organizaciones cumplan cabalmente con sus valores (que deben establecerlos y exponerlos públicamente), para que los mismos puedan ser aplicados en relación con todos los actores sociales.

Sin embargo, todo lo anterior debe articularse dentro del contexto de un país agrícola y dependiente de la extracción de sus recursos naturales (como es el caso de Argentina), en donde los sectores agroalimenticios e industriales juegan un rol fundamental en el escenario económico, al igual que en las proyecciones sobre el crecimiento demográfico, sostenibilidad de las ciudades, y en la relación con la reducción de la pobreza.

El Plan Estratégico Agroalimentario y Agroindustrial Participativo y Federal 2010-2020 (Ministerio de Agricultura, Ganadería y Pesca, s/f $f^{6}$ ) tiene como objetivo aumentar la producción y agregar valor en origen para garantizar la soberanía alimentaria e incrementar las ventas externas involucrando y comprometiendo a todos los actores relevantes del sector agroalimentario o agroindustrial (Minaverry y Gally, 2014). Para cumplir este plan se deberán obtener productos con valor agregado, los cuales deberán ser obtenidos mediante la aplicación de un enfoque obtenido de la implementación de trabajo interdisciplinario.

Por su parte, el Instituto Nacional de Tecnología Agropecuaria establece que las empresas agropecuarias, forestales y agroindustriales se encuentran insertas en un territorio geográfico, caracterizado por una base de recursos naturales específicos, una identidad (historia y cultura) local donde las relaciones sociales, instituciones y organizacionales conforman un tejido o entramado socio-institucional (Consejo Profesional Ingeniería Agronómica, 2014). En este contexto se puede observar en forma clara que se han ido incorporando las problemáticas sociales dentro del ámbito de la producción agropecuaria argentina.

Analizando estas posiciones vinculadas con el enfoque productivo es posible vislumbrar que actualmente no solo se hace referencia al manejo de los temas técnicos, sino que también se ha incluido la problemática social dentro del ámbito de trabajo de los profesionales encargados de tomar decisiones. of an organization to behave in an ethical manner, and to collaborate with economic development and with the improvement of the community's quality of life. Also, it attempts to ensure that all organizations comply fully with their values (which must be established and exposed publicly), so that they can be applied in relation to all the social actors.

However, all of this must be articulated within the context of an agricultural country that depends on the extraction of its natural resources (as is the case of Argentina), where the agrifood and industrial sectors play a fundamental role in the economic scenario, the same as in projections regarding demographic growth, sustainability of cities, and in relation to poverty reduction.

The Strategic Agrifood and Agroindustrial Participative and Federal Plan 2010-2020 (Plan Estratégico Agroalimentario y Agroindustrial Participativo y Federal 2010-2020), (Ministerio de Agricultura, Ganadería y Pesca, s/f ${ }^{6}$ ) has the objective of increasing production and adding value at origin to ensure dietary sovereignty and increase the external sales, committing all the relevant actors of the agrifood or agroindustrial sector (Minaverry and Gally, 2014). To fulfill this plan, products with added value should be obtained, which ought to be obtained through the application of an approach derived from the implementation of interdisciplinary work.

In turn, the National Institute of Agricultural and Livestock Technology (Instituto Nacional de Tecnologia Agropecuaria) establishes that agricultural and livestock, forestry, and agroindustrial enterprises are inserted in a geographic territory, characterized by a base of specific natural resources, local identity (history and culture) where social, institutional and organizational relationships make up a socio-institutional fabric or framework (Consejo Profesional Ingeniería Agronómica, 2014). In this context, it can be observed clearly that social problems have been incorporated into the scope of Argentinian agricultural and livestock production.

Analyzing these postures linked to the productive approach, it is possible to surmise that currently there is reference not only to the management of technical issues, but that the social problematic has also been included within the scope of the work of professionals in charge of decision making. Likewise, some authors have established that graduate studies 
Asimismo, algunos autores han establecido que los estudios de posgrado en cuestiones ambientales se enfocan en cuatro líneas: monitoreo y análisis ambiental y ecológico, planeamiento. Los estudios de grado, ingenierías y licenciaturas se enfocan prioritariamente hacia las ciencias de la tierra, complementadas con algunos cursos sobre administración o política ambiental, y unos pocos se acercan a la economía, a la sociología o a la antropología (Carrizosa, 2007).

El objetivo de este trabajo es exponer los aspectos centrales descriptos por una selección de instrumentos internacionales, cuyos contenidos justifican la incorporación de la "educación ambiental" en los programas de las carreras universitarias, en especial en las vinculadas con el ámbito productivo, como es el caso de las ingenierías.

Nuestra hipótesis de trabajo se basa en que todos los conceptos que se derivan de dichos instrumentos (sobre sostenibilidad, producción limpia y educación ambiental) son fundamentales para lograr una formación integral de los profesionales. En este sentido, los egresados de carreras universitarias y de posgrado que se vinculan con estas áreas habitualmente se encuentran a cargo de implementar una serie de procesos productivos, cuya ejecución involucra diversas decisiones en relación con la aplicación de prácticas sostenibles o no sostenibles.

\section{Metodología y Justificación del Trabajo}

Se trata de una investigación de carácter exploratorio; su estructura es de tipo bibliográfico-documental y descriptiva, y la metodología utilizada es cualitativa. Se ha recurrido a diversas fuentes y técnicas de recolección de datos y se consultaron estudios académicos, información estadística, fuentes judiciales, materiales oficiales y públicos. Como técnica de análisis se ha utilizado a la hermenéutica de textos normativos y de documentos públicos.

El ámbito temporal seleccionado para el análisis de instrumentos internacionales y de normas voluntarias y obligatorias abarca desde 1972 hasta la actualidad, ya que en dicho año se ha elaborado la Declaración de Estocolmo dentro del ámbito de la Conferecia de Naciones Unidas para el medio humano, estableciendo responsabilidad directa en el hombre en relación al estado en el que se encuentra el ambiente. in environmental matters are focused on four lines: environmental and ecological monitoring and analysis, planning. Graduate studies, engineering and bachelor's degrees are focused primarily on earth sciences, complemented with some courses in administration or environmental policy, and a few approach economics, sociology or anthropology (Carrizosa, 2007).

The objective of this study is to expose the central aspects described by a selection of international instruments, whose contents justify the incorporation of "environmental education" into the programs of university careers, especially those linked to the productive area, as is the case of engineering branches.

Our working hypothesis is based on the idea that all concepts that are derived from such instruments (about sustainability, clean production and environmental education) are fundamental to achieve an integral training of professionals. In this sense, graduates from university careers and graduate studies who are linked with these areas are habitually in charge of implementing a series of productive processes, whose execution involves various decisions in relation to the application of sustainable or unsustainable practices.

\section{Methodology and Justification OF THE STUDY}

This is research of an exploratory nature; its structure is bibliographic-documental and descriptive, and the methodology used is qualitative. Various sources and data collection techniques have been used and academic studies, statistical information, legal sources, official and public materials were consulted. The hermeneutics of normative texts and public documents has been used as analysis technique.

The temporal scope selected for the analysis of international instruments and voluntary and mandatory regulations covers from 1972 until today, since in that year the Stockholm Declaration was made within the sphere of the United Nations Conference for the Human Environment, establishing the direct responsibility of man in relation to the state in which the environment is found.

The main justification for the elaboration of this study lies in that a lack of training and environmental education has been detected in local communities and, especially, in students of degree 
La principal justificación para la elaboración del presente trabajo radica en que se ha detectado una falta de capacitación y educación ambiental en las comunidades locales y, en especial, de los estudiantes de las carreras de grado (niveles universitarios y vinculados con el área productiva). Esta ha sido una de las mayores debilidades detectadas a nivel nacional y se ha vislumbrado en el ámbito docente de grado y de posgrado de universidades públicas y privadas de Argentina durante el período de diez años (20072017).

Esta realidad dificulta mucho la comprensión de aspectos globales de las asignaturas impartidas en las carreras de Ingeniería Agronómica (Manejo integrado de plagas) y de maestrías en ingeniería en calidad y en especializaciones sobre higiene, seguridad y protección ambiental respecto de las cuales se proveerá información directa de los autores.

Los alumnos que asisten a dichas carreras presentan distinta formación académica, ya que se trata de grupos interdisciplinarios, en su mayoría ingenieros, quienes desconocen aspectos relevantes vinculados con la educación y el derecho ambiental y con la Responsabilidad Social. Esta situación acompañada por el bajo presupuesto asignado para la educación ambiental por parte de las autoridades públicas ha maximizado la problemática hasta tal punto que los alumnos desconocen los lineamientos centrales y la existencia de normativa relevante y vigente (como es el caso de la ley nacional de residuos peligrosos $\mathrm{N}^{\circ}$ 24.051 que posee un régimen sancionatorio penal) y que podría afectarles gravemente en su persona.

\section{Resultados y Discusión}

\section{Consideraciones sobre la normativa jurídica sobre educación ambiental en el ámbito de Argentina}

La ex Secretaría de Ambiente y Desarrollo Sustentable de la Nación avanzó con la elaboración de una Estrategia Nacional de Educación Ambiental a partir del año 2006. La misma fue definida como el proceso que posibilita construir participativamente los lineamientos de la política nacional de educación ambiental y que permite desarrollar programas de manera conjunta y coordinada con las reparticiones oficiales nacionales, provinciales y municipales, así como con las $\mathrm{ONG}$ vinculadas con esta temática. careers (university levels and linked to the productive area). This has been one of the greatest weaknesses detected at the national level and it has been seen in the teaching sphere for degree and graduate studies of public and private universities in Argentina during the period of ten years (2007-2017).

This reality makes the comprehension of global aspects of the courses taught in the careers of Agronomic Engineering (Integrated management of pests) difficult, as well as in master's programs in quality engineering and specializations about hygiene, safety and environmental protection regarding which information will be provided directly from the authors.

The students that attend these careers present different academic training, since they are interdisciplinary groups, mostly engineers, who ignore relevant aspects connected to environmental education and law, and to Social Responsibility. This situation, along with the low budget allotted to environmental education by public authorities, has maximized the problematic to the point where students ignore the central guidelines and existence of relevant and current regulations (as is the case of the national law for dangerous wastes $\mathrm{N}^{\circ}$ 24.051, which has a legal penalizing regime), and which could gravely affect them personally.

\section{Results AND Discussion}

\section{Considerations about legal regulations on environmental education in the Argentinian scope}

The former Ministry of the Environment and Sustainable Development of the Nation advanced with the elaboration of a National Strategy of Environmental Education starting in the year 2006. It was defined as the process that makes possible building in a participative manner the guidelines of the national policy on environmental education and which allows developing programs in a joint and coordinate manner with the official national, provincial and municipal shares, as well as with the NGOs linked to this subject.

This non-binding tool (since it is not a mandatory legal regulation) has an initial impact on the process that is being described as having as one of its objectives to elaborate, communicate and keep updated and 
Esta herramienta no vinculante (ya que no se trata de una norma jurídica obligatoria) posee un impacto inicial en el proceso que se está describiendo al tener como uno de sus objetivos el de elaborar, difundir y mantener actualizado y disponible para su utilización un estudio diagnóstico sobre la problemática de la evaluación de impacto ambiental que contemple las diferentes realidades en Argentina. Además, se proponía identificar necesidades, intereses y prioridades del país referido a los actores y grupos clave a través de la participación comunitaria y asegurar el derecho de acceso a la información relacionada con la educación ambiental a todos los sectores sociales.

Uno de los propósitos fundamentales de la educación ambiental es lograr que tanto los individuos como las comunidades comprendan la naturaleza compleja del ambiente (resultante de la interacción de sus diferentes aspectos: físicos, biológicos, sociales, culturales, económicos, entre otros) y adquieran los conocimientos, los valores y las habilidades prácticas para participar responsable y eficazmente en la prevención y solución de los problemas ambientales y en la gestión de la calidad del medio (Martínez Huerta, s/f).

Todo lo anterior había sido incorporado en la Estrategia Nacional de Educación Ambiental, que no llegó a replicarse en una norma jurídica obligatoria, ya que los proyectos de leyes que tramitaron ante el Congreso de la Nación perdieron sistemáticamente estado parlamentario (o sea que no fueron aprobados dentro del lapso de dos años).

A su vez, en el nivel inicial educativo aún no se ha incorporado la asignatura "Educación Ambiental" como obligatoria dentro de la currícula oficial, por lo que tampoco existen muchos antecedentes de producción de material vinculados con la misma. A su vez, cuando se hace referencia a niveles superiores de educación o de investigación en dicha área, la tendencia observada en la mayoría de los casos es la escasa transferencia de conocimientos desde la comunidad científica hacia la sociedad.

Por su parte, la tendencia observada por parte del Derecho Ambiental argentino es la de proteger legalmente a los recursos hídricos y a los bosques por separado (Minaverry, 2011), salvo por aisladas y recientes excepciones normativas y jurisprudenciales. Es decir, se han conformado dispositivos normativos que regulan de forma sectorial a los usos, su protección y remediación, por un lado en lo que concierne available for their use a diagnostic study about the problematic of the environmental impact evaluation that contemplates the different realities in Argentina. In addition, there was the purpose of identifying needs, interests and priorities of the country referring to the key actors and groups through community participation and ensuring the right of access to the information related with environmental education for all the social sectors.

One of the fundamental aims of environmental education is to achieve the understanding by both individuals and communities of the complex nature of the environment (which results from the interaction of its different aspects: physical, biological, social, cultural, economic, among others), and to acquire the knowledge, values and practical abilities to participate responsibly and efficiently in the prevention and solution of environmental problems and in the management of the environment's quality (Martínez Huerta, s/f).

All of this had been incorporated into the National Strategy for Environmental Education, which was not replicated in a mandatory legal regulation, since the law projects that were negotiated before the Congress of the Nation systematically lost the parliamentary status (that is, they were not approved within the lapse of two years).

In turn, at the initial educational level the subject "Environmental Education" has not yet been incorporated as mandatory within the official curriculum, which is why there are also not many records of material production linked to it. At the same time, when there is reference to higher levels of education or research in this area, the trend observed in most of the cases is the scarce transference of knowledge from the scientific community towards society.

In their turn, the trend observed by Argentinian Environmental Law is to legally protect the water resources and the forests separately (Minaverry, 2011), except for the isolated and recent normative and jurisprudence exceptions. That is, normative mechanisms have been set up that regulate in a sectorial way the uses, protection and remediation, on the one hand, in terms of water resources, and on the other hand forests, as it happens with other natural resources. This is observed not only in the normative aspect but rather in the organizational management mechanism that sustains and fixes what 
a los recursos hídricos, y por otro a los bosques, al igual que ocurre con los otros recursos naturales. Esto se observa no solo en lo normativo sino también en el dispositivo de gestión organizacional que sostiene y concreta lo estipulado en la normativa vigente, caracterizado por un conjunto de ministerios, secretarías, organismos y entes públicos, lo cual se replica en los programas que desarrollan e implementan.

Es conocido que tanto el sector público, las $\mathrm{ONG}$, las instituciones educativas, los medios de comunicación y la población en general tienen un rol muy importante respecto de la difusión y educación en dicha área. Todos ellos colectivamente deben imponer presión para tender a lograr dicho objetivo (Nelliyat y Ambujan, 2011). Otro punto a considerar son los Consejos Profesionales, quienes también deberían involucrarse dentro del ámbito de la responsabilidad del ejercicio de las profesiones que representan.

\section{El aporte de las normas voluntarias: la Responsabilidad Social}

Las normas y guías ISO describen una metodología tendiente a la mejora continua de los procesos para aumentar el desempeño de la organización y beneficiar a las partes interesadas. Las mismas son normas voluntarias y certificables (salvo en el caso de la guía ISO 26,000) que aseguran un control real por una tercera parte reconocida y sirven para identificar claramente los procesos, los problemas y brindan las oportunidades de mejora al detectar no conformidades y conducen a la forma de actuar.

En la Figura 1 se tratará de explicar, solo a modo informativo, cómo las producciones sostenibles se relacionan con la gestión de calidad (Gally y Giachino, 2014).

En Argentina existen escasas normas obligatorias que centren su atención en el respeto de las cuestiones éticas y además existen lagunas jurídicas en la regulación sobre los mecanismos de control de las actuaciones públicas (Minaverry y Gally, 2013). Luego, en relación con las normas jurídicas vigentes y obligatorias para nuestro país y que se vinculan con la Responsabilidad Social, podemos afirmar que las mismas no han incorporado aún todos los conceptos fundamentales de las normas voluntarias destacadas en el trabajo. En este sentido se pueden mencionar a nivel nacional las leyes $\mathrm{N}^{\circ}$ 24,127 (Premio Nacional de la Calidad), N $\mathrm{N}^{\circ} 25,855$ (Voluntariado Social), y el is stipulated in the current regulations, characterized by a set of ministries, secretariats, organizations and public entities, which is replicated in the programs that are developed and implemented.

It is known that the public sector, NGOs, educational institutions, communication media, as well as the population at large have a very important role with regards to the diffusion and education in this area. All of these collectively must impose pressure to tend to achieve the objective (Nelliyat and Ambujan, 2011). Another point to consider is Professional Councils, which should also be involved within the sphere of the responsibility of the exercise of professions that they represent.

\section{The contribution of voluntary regulations: Social Responsibility}

The regulations and ISO guides describe a methodology that tends to the continuous improvement of processes to increase the performance of the organization and to benefit the parts interested. These are voluntary and certifiable regulations (except in the case of the ISO 26,000 guide), which ensure a real control by a recognized third part and serve to clearly identify the processes, problems and to provide the opportunities for improvement when detecting non-conformities and to lead in the way of acting.

Figure 1 will try to explain, only informatively, how sustainable productions are related to quality management (Gally and Giachino, 2014).

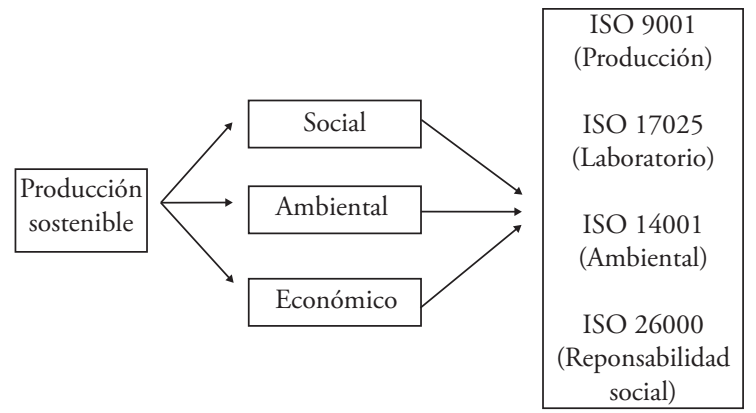

Fuente: Gally T., Giachino, M. V., 2014 * Source: Gally T., Giachino, M. V., 2014.

Figura 1. Aspectos de la producción sostenible. Figure 1. Aspects of sustainable production. 
artículo 25 de la Ley $\mathrm{N}^{\circ}$ 25,877 (Balance Social), que regulan parcialmente algunos aspectos vinculados con la responsabilidad social. Asimismo, en el ámbito de la Ciudad Autónoma de Buenos Aires existe normativa con conceptos similares.

A su vez, cabe destacar que Argentina ha ratificado diversos instrumentos internacionales y que, de acuerdo con nuestro sistema jurídico, los mismos han sido incorporados como normativa interna a través del dictado de leyes nacionales. Tal es el caso de la Declaración Universal de Derechos Humanos, del Pacto Internacional de Derechos Civiles y Políticos, del Pacto Internacional de Derechos Económicos, Sociales y Culturales, entre otros. A través del análisis de la guía ISO 26,000 vigente se pueden detectar diversos puntos de contacto con los fundamentos y principios de dichos instrumentos internacionales.

Para el caso de la Responsabilidad Social, los puntos 6.5.4.1 y 6.5.4.2 hacen referencia al uso sostenible de los recursos naturales, a las acciones y a las expectativas vinculadas directamente con la temática del presente trabajo. Esta norma fue publicada en el mes de noviembre de 2010 y cubre en su totalidad a los tres ámbitos en los que se concentra el "Desarrollo Sostenible” (Minaverry, López y Gally, 2012).

El punto 6.8.4.denominado asunto 2 sobre participación activa y desarrollo de la comunidad: educación y cultura, plantea que la educación y la cultura constituyen la base del desarrollo social y económico y son parte de la identidad de la comunidad. La preservación y la promoción de una cultura y de una educación teniendo en cuenta el cumplimiento de los derechos humanos pueden otorgar un impacto positivo promoviendo la cohesión social y el desarrollo. Además, una organización debería promover y apoyar la educación en todos los niveles e involucrarse en acciones que mejoren la calidad y el acceso a la misma, a su vez, promover el conocimiento local.

El punto 6.8.5., denominado asunto 3 sobre participación activa y desarrollo de la comunidad: creación de empleo y desarrollo de habilidades, establece que con la creación del empleo todas las organizaciones pueden hacer una contribución a la reducción de la pobreza y la promoción del desarrollo económico y social. El desarrollo de habilidades es un componente esencial de la promoción de empleo y de la ayuda a las personas a garantizar trabajos decentes y productivos.

El punto 6.8.6., denominado asunto 4 sobre participación activa y desarrollo de la comunidad:
In Argentina there are scarce mandatory regulations that center their attention in the respect of ethical matters and there are also legal lapses in the regulation of control mechanisms for public actions (Minaverry y Gally, 2013). Then, in relation to the current and mandatory regulations for our country and which are linked to Social Responsibility, we can state that these have not incorporated yet all the fundamental concepts of voluntary regulations highlighted in the study. In this sense, at the national level the following laws can be mentioned: $\mathrm{N}^{\circ}$ 24,127 (National Quality Award), No 25,855 (Social Voluntary Work), and article 25 of Law $\mathrm{N}^{\circ}$ 25,877 (Social Balance), which partially regulate some aspects linked to social responsibility. Likewise, in the sphere of the Autonomous City of Buenos Aires there are regulations with similar concepts.

In turn, it should be highlighted that Argentina has ratified various international instruments and which, according to our legal system, these have been incorporated as internal regulations through the dictates of national laws. This is the case of the Universal Declaration of Human Rights, the International Pact of Civil and Political Rights, the International Pact of Economic, Social and Cultural Rights, among others. Through the analysis of the current ISO 26,000 guide various contact points can be detected with the foundations and principles of these international instruments.

For the case of Social Responsibility, the points 6.5.4.1 and 6.5.4.2 refer to the sustainable use of natural resources, the actions and the expectations linked directly to the theme of this study. This norm was published in the month of November 2010 and covers in its totality the three areas on which "Sustainable Development" focuses (Minaverry, López and Gally, 2012).

Point 6.8.4., called issue 2, about active participation and community development: education and culture, suggests that education and culture constitute the basis of social and economic development, and are part of the community identity. The preservation and promotion of a culture and of education taking into account the fulfillment of human rights can have a positive impact promoting social cohesion and development. In addition, an organization should promote and support education at all levels and become involved in actions that 
desarrollo y acceso a la tecnología, afirma que "las organizaciones pueden contribuir al desarrollo de las comunidades en las que operan aplicando conocimientos, habilidades y tecnologías especializadas, de una manera que promueva el desarrollo de los recursos humanos y la difusión de la tecnología." El acceso a la información es clave para superar las disparidades que existen entre países, regiones, generaciones, géneros, entre otros.

El punto 6.8.9., denominado asunto 7 sobre la participación activa y desarrollo de la comunidad, establece que "la inversión social aparece cuando las organizaciones invierten en iniciativas y programas orientados a mejorar aspectos sociales de la vida en comunidad. Los tipos de inversiones sociales podrían incluir proyectos relacionados con educación, formación, cultura, cuidado de la salud, generación de ingresos, entre otras cuestiones.

Luego el punto 6.5.1.2 establece que la responsabilidad ambiental resulta ser previa para la supervivencia y prosperidad de los seres humanos. Hace referencia específica a la "educación ambiental" y a que la creación de capacidad es fundamental para promover el desarrollo de sociedades y estilos de vida sostenibles. Esto se fundamenta en que actualmente existen diversos desafíos ambientales (como es el del cambo climático) que deberán ser enfrentados por ciudadanos formados con un enfoque orientado hacia la protección ambiental integral.

En este sentido, las organizaciones deberían también fomentar la participación activa de la comunidad en el diseńo y la implementación de proyectos, ya que esto supone potenciar sinergias en términos estructurales y también aquellas que puedan propender a la interrelación entre actividades productivas y no productivas (vínculos ente agricultura, industria y servicios).

Es importante destacar que en trabajos anteriores se ha determinado, a través del análisis de textos jurídicos ambientales vigentes y de la misma guía ISO 26000 , que esta última adoptó diversos principios incluidos en las leyes ambientales obligatorias argentinas que ya habían sido dictadas con anterioridad (Minaverry, Gally y Pantuso, 2016).

\section{Análisis de una selección de instrumentos internacionales ambientales y sociales}

\section{a) Los objetivos de desarrollo del Milenio (2000- 2015)}

improve the quality and access to it, and in turn, promote local knowledge.

Point 6.8.5., called issue 3, about active participation and community development: creation of employment and development of abilities, establishes that with the creation of employment all the organizations can make a contribution to poverty reduction and to the promotion of economic and social development. The development of abilities is an essential component of the promotion of employment and of support to people to ensure decent and productive jobs.

Point 6.8.6., called issue 4, about active participation and community development: development and access to technology, states that "organizations can contribute to the development of the communities in which they operate applying knowledge, abilities and specialized technologies, in a manner that promotes the development of human resources and the diffusion of technology." Access to information is something key to overcome the disparities present between countries, regions, generations, genders, among others.

Point 6.8.9., called issue 7, about active participation and community development, establishes that "social investment appears when organizations invest in initiatives and programs directed at improving social aspects of life in the community. The types of social investments could include projects related to education, training, culture, health care, income generation, among other issues.

Then, point 6.5.1.2 establishes that environmental responsibility turns out to be prior to the survival and prosperity of human beings. It refers specifically to "environmental education" and to the fact that creating capacity is fundamental to promote the development of societies and sustainable lifestyles. This is based on the fact that there are currently various environmental challenges (such as climate change), which will need to be faced by trained citizens with an approach directed at integral environmental protection.

In this sense, organizations should also promote the active participation of the community in the design and the implementation of projects, since this entails potentiating synergies in structural terms and also those that can tend to the interrelation between productive and non-productive activities (links between agriculture, industry and services). 
En la sede de las Naciones Unidas en Nueva York, en septiembre de 2000 se celebró la Cumbre del Milenio, donde participaron 147 Jefes de Estado y de Gobierno y los 189 Estados Miembros de las Naciones Unidas. Los líderes mundiales allí reunidos acordaron dar respuesta a algunos de los desafíos más importantes del siglo XXI mediante el enunciado de objetivos y metas a cumplir mensurables para el año 2015.

Su finalidad fue la de comprometer a los países a tomar nuevas medidas y aunar esfuerzos en la lucha contra la pobreza, analfabetismo, hambre, falta de educación, desigualdad entre los géneros, mortalidad infantil y materna, enfermedad y degradación del ambiente. Asimismo, el último objetivo insta a los países ricos a adoptar medidas para aliviar la deuda externa, incrementar la asistencia económica y permitir a los países más pobres el acceso a los mercados y la tecnología (Giuffré , 2004).

Dentro de estos objetivos, cabe destacar los que brindan un aporte importante a la temática de análisis:

\section{Objetivo 2: Lograr la enseñanza primaria universal}

A pesar que el mismo no hace referencia específica a la educación ambiental se proponía asegurar que en 2015 los niños y niñas de todo el mundo puedan terminar un ciclo completo de enseñanza primaria.

\section{Objetivo 7: Garantizar la sostenibilidad del medio ambiente}

Las metas específicas eran las de incorporar los principios del desarrollo sostenible en las políticas nacionales a fin de disminuir la pérdida de recursos del medio al ambiente. Sin embargo, las políticas para cumplir el séptimo objetivo acerca de la sostenibilidad no pueden obviar una adecuada gestión ambiental de los recursos naturales y un mayor esfuerzo en el fortalecimiento de la educación en todos los niveles.

Estos objetivos finalizaron en 2015, dando lugar a un informe final de cumplimiento, que ante su escaso avance en el logro de sus metas dio paso a la elaboración de 17 nuevos objetivos de desarrollo sostenible los cuales serán comentados a continuación.

\section{b) Objetivos de desarrollo sostenible (2015-2030)}

It is important to highlight that in previous studies it has been determined, through the analysis of current environmental legal texts and the same guide ISO 26,000, that the latter adopted various principles included in the Argentinian mandatory environmental laws that had already been dictated before (Minaverry, Gally and Pantuso, 2016).

\section{Analysis of a selection of international environmental and social instruments}

\section{a) The Millennium Development Goals (2000- 2015)}

At the United Nations headquarters in New Yok, in September 2000, the Millennium Summit was celebrated, where 147 Heads of State and of Government participated and 189 State Members of the United Nations. The world leaders united there agreed to respond to some of the most important challenges of the $21^{\text {st }}$ century through the declaration of measurable objectives and goals to be fulfilled by the year 2015 .

Its goal was to commit the countries to take new measures and combine efforts in the fight against poverty, illiteracy, hunger, lack of education, inequality between genders, child and maternal mortality, disease and degradation of the environment. Likewise, the last goal urges the rich countries to adopt measures to relieve external debt, increase economic assistance, and allow the poorest countries access to markets and technology (Giuffré, 2004).

Within these goals, the ones that provide an important contribution to the theme of analysis should be highlighted:

\section{Goal 2: Achieving universal primary education}

Although it does not refer specifically to environmental education, it proposes ensuring that in 2015 boys and girls throughout the world can finish a complete cycle of primary education.

\section{Goal 7: Ensuring the sustainability of the environment}

The specific goals were those of incorporating the principles of sustainable development into national policies in order to decrease the loss of resources from the environment. However, the policies to fulfill the 
Uno de los principales avances implementados a partir de la Cumbre de Río + 20 de las Naciones Unidas para el Desarrollo Sostenible y en el documento denominado "Transformando nuestro mundo: Agenda 2030 para el desarrollo sostenible" fue que se incluyeron un conjunto de 17 Objetivos de Desarrollo Sostenible (ODS) y 169 metas que se proponen poner fin a la pobreza y al hambre en todo el mundo a 2030, combatir las desigualdades dentro de los países $y$, entre ellos, construir sociedades pacíficas entre otras cuestiones fundamentales para mejorar la calidad de vida de la humanidad (Minaverry y Martínez, 2016). En particular, resulta relevante destacar a los siguientes objetivos que se vinculan directamente con los lineamientos planteados a lo largo del presente trabajo:

Objetivo 4: Garantizar una educación inclusiva, equitativa y de calidad y promover oportunidades de aprendizaje durante toda la vida para todos:

Una de las metas del mismo resulta ser muy importante, en tanto que para 2030 se propone "garantizar que todos los alumnos adquieran los conocimientos teóricos y prácticos necesarios para promover el "desarrollo sostenible", entre otras herramientas, mediante la educación y la adopción de estilos de vida sostenibles, respetando los derechos humanos, la igualdad entre los géneros, la promoción de una cultura de paz y no violencia, la ciudadanía mundial y la valoración de la diversidad cultural y de la contribución de la cultura al desarrollo sostenible, entre otros medios".

Objetivo 9: Construir infraestructuras resilientes, promover la industrialización inclusiva y sostenible y fomentar la innovación.

Sus metas se enfocan en promover una industrialización inclusiva y sostenible y, a más tardar en 2030, aumentar de manera significativa la contribución de la industria al empleo y al producto bruto interno, de acuerdo con las circunstancias nacionales y duplicar esa contribución en los países menos desarrollados.

Asimismo, se proponen para 2030 mejorar la infraestructura y reajustar las industrias para que sean sostenibles, utilizando los recursos con mayor eficacia y promoviendo la adopción de tecnologías y de procesos industriales limpios y ambientalmente racionales, y logrando que todos los países adopten medidas de acuerdo con sus capacidades respectivas. seventh goal regarding sustainability cannot omit an adequate environmental management of natural resources and a greater effort in the strengthening of education at all levels.

These goals ended in 2015, giving place to a final report of compliance, which in the face of scarce advance in the attainment of the objectives resulted in the elaboration of 17 new sustainable development goals which will be discussed next.

\section{b) Sustainable Development Goals (2015-2030)}

One of the main advances implemented since the United Nations Rio Summit + 20 for Sustainable Development and in the document called "Transforming our world: Agenda 2030 for sustainable development" was that a set of 17 Sustainable Development Goals (SDG) were included, and 169 goals proposed, to end poverty and hunger throughout the world by 2030, fighting inequalities inside countries and between them, and build peaceful societies, among other fundamental issues to improve the humanity's quality of life (Minaverry y Martínez, 2016). In particular, it is relevant to highlight the following objectives that are linked directly to the guidelines presented in this study:

Objective 4: Ensuring an inclusive, equitable and quality education, and promoting learning opportunities throughout life for everyone:

One of the goals of this objective turns out to be very important, since by 2030 there is "the proposal to guarantee that all students acquire the theoretical and practical knowledge necessary to promote "sustainable development", among other tools, through education and adoption of sustainable lifestyles, respecting human rights, gender equality, promotion of a peace and non-violence culture, global citizenship, and valuation of cultural diversity and the contribution of culture to sustainable development, among other media".

\section{Objective 9: Building resilient infrastructures, promoting inclusive and sustainable industrialization, and fostering innovation.}

Its goals are focused on promoting an inclusive and sustainable industrialization, and by 2030 at 


\section{Objetivo 12: Garantizar modalidades de consumo y producción sostenibles.}

Las metas fundamentales que se vinculan con el presente son las siguientes: aplicar el Marco Decenal de Programas sobre Modalidades de Consumo y Producción Sostenibles, con la participación de todos los países y bajo el liderazgo de los países desarrollados, teniendo en cuenta el grado de desarrollo y las capacidades de los países en desarrollo.

Para 2030, lograr la gestión sostenible y el uso eficiente de los recursos naturales, y para 2020 conseguir la gestión ecológicamente racional de los productos químicos y de todos los desechos a lo largo de su ciclo de vida, de conformidad con los marcos internacionales convenidos, y reducir de manera significativa su liberación a la atmósfera, el agua y el suelo, a fin de reducir al mínimo sus efectos adversos en la salud humana y el medio ambiente.

\section{c) Pacto global}

La iniciativa del Pacto Global fue presentada por el Secretario General de las Naciones Unidas en el Foro Económico Mundial en enero de 1999. El Pacto Global es una iniciativa voluntaria que intenta promover la responsabilidad social, o sea, se trata de una declaración voluntaria que abarca distintas temáticas, en la cual una organización decide adherir a diez principios y se compromete públicamente a exponer sus resultados. En este sentido resaltaremos los aspectos que se vinculan con la temática analizada en el presente trabajo:

Ámbito del medio ambiente:

- Apoyar el enfoque preventivo frente a los retos medioambientales.

- Promover mayor responsabilidad medioambiental.

- Alentar el desarrollo y la difusión de tecnologías respetuosas del medio ambiente.

El Pacto Global puede verse como un instrumento cuyo objetivo es que se logre tomar conciencia y actuar sobre la comunidad vinculada al negocio (consumidores, trabajadores, competidores, proveedores, entre otros). En Argentina tuvo amplia aceptación ${ }^{7}$ y dentro del ámbito ambiental se destacan the latest, increasing significantly the industry's contribution to employment and to the gross domestic product, according to the national circumstances, and duplicating this contribution in the least developed countries.

Likewise, improving the infrastructure by 2030 is proposed and readjusting industries for them to be sustainable, using resources with higher efficacy and promoting the adoption of technologies and of clean and environmentally rational industrial processes, and attaining for all countries to adopt measures of agreement with their respective capacities.

\section{Objective 12: Ensuring sustainable modalities of consumption and production.}

The fundamental goals that are linked to this objective are the following: applying the Ten-year Framework of Programs on Modalities of Sustainable Consumption and Production, with the participation of all countries and under the leadership of developed countries, taking into account the degree of development and the capacities of developing countries.

By 2030, attaining sustainable management and the efficient use of natural resources, and by 2020 achieving the ecologically rational management of chemical products and all wastes throughout their life cycle, in compliance with the international frameworks agreed upon, and reducing significantly their liberation to the atmosphere, the water and the soil, with the aim of reducing to the minimum their adverse effects on human health and the environment.

\section{c) Global Pact}

The initiative of the Global Pact was presented by the General Secretary of the United Nations in the World Economic Forum in January 1999. The Global Pact is a voluntary initiative that attempts to promote social responsibility, that is, it is a voluntary declaration that covers different themes, in which an organization decides to adhere to ten principles and commits publicly to expose its results. In this sense, we will highlight the aspects that are linked to the thematic analyzed in this study:

Environmental sphere:

- To support the preventive approach in face of environmental challenges. 
los siguientes principios, que a su vez se encuentran plasmados en otros instrumentos internacionales:

\section{Principio 7: Apoyar el enfoque preventivo frente a los retos medioambientales}

La Declaración de Río propone una idea extremadamente importante, que es mantener un enfoque preventivo en favor de la protección medioambiental, que implica tener en cuenta los riesgos que deberán afrontar las generaciones futuras si se ponen en peligro los ecosistemas.

\section{Principio 8: Promover mayor responsabilidad medioambiental}

Se refiere a alentar dentro del ámbito de influencia de la organización una mayor responsabilidad respecto del medio ambiente.

\section{Principio 9: Alentar el desarrollo y la difusión de tecnologías respetuosas del medio ambiente:}

"La Agenda 21 menciona las tecnologías medioambientalmente saludables como aquellas que protegen el medio ambiente, contaminan menos, utilizan los recursos de una forma sostenible, reciclan más sus vertidos y productos, y manejan los residuos de una manera más aceptable que las tecnologías a las cuales sustituyen. No se trata de tecnologías meramente individuales, sino de sistemas integrales que incluyen know-how, procedimientos, productos y servicios y equipos, así como procesos que mejoran la organización y la gestión medioambiental."

\section{Conclusiones}

A lo largo del presente trabajo se han analizado y extraído lineamientos básicos vinculados con la sostenibilidad, con lograr una producción más limpia y con el fomento de una educación ambiental, los cuales fueron apareciendo en una serie de instrumentos internacionales, en una guía voluntaria sobre Responsabilidad Social y en normativa obligatoria vigente en Argentina. En este sentido podemos establecer que para favorecer una educación que incorpore dichos conceptos sería conveniente modificar algunas estructuras curriculares y resaltar la dimensión socio-ambiental, el enfoque
- To promote greater environmental responsibility.

- To foster the development and diffusion of technologies that are respectful of the environment.

The Global Pact can be seen as an instrument whose aim is to attain awareness and to act in the community linked to business (consumers, workers, competitors, providers, among others). In Argentina, it had broad acceptance ${ }^{7}$ and the following principles stand out within the environmental sphere, which in turn are expressed in other international instruments:

\section{Principle 7: Support the preventive approach in} face of environmental challenges

The Rio Declaration proposes an extremely important idea, which is maintaining a preventive approach in favor of environmental protection, which implies taking into account the risks that future generations will have to face if ecosystems are in danger.

\section{Principle 8: Promote greater environmental responsibility}

It refers to encouraging a higher responsibility with regards to the environment within the scope of influence of the organization.

Principle 9: Encourage the development and the diffusion of technologies respectful of the environment:

"The Agenda 21 mentions healthy environmental technologies such as those that protect the environment, contaminate less, use resources in a sustainable manner, recycle more their spills and products, and manage the residues in a more acceptable way than the technologies which they substitute. It is not about merely individual technologies, but rather integral systems that include know-how, procedures, products and services, and equipment, as well as processes that improve the environmental organization and management."

\section{Conclusions}

Throughout this study, the basic guidelines linked to sustainability have been analyzed and extracted, as 
interdisciplinario y el fortalecimiento de las relaciones interinstitucionales para poder transmitir los conceptos correctamente.

Esto tiene su fundamento en que la educación ambiental es la única capaz de construir la conciencia colectiva sobre el valor del ambiente y la necesidad de cuidarlo y recuperarlo (Mathus Escorihuela, 2011). La misma hace referencia a un salto cualitativo con respecto a la formación, ya que se centra en la dimensión moral del ser humano, o sea que implica puesta en práctica (la conducta) de lo que conceptualmente se aprecia y considera valioso de acuerdo con la idea global de vida que se posea (García, 2010).

La generación de conocimiento interdisciplinario resulta ser un enfoque fundamental y proporciona un soporte sólido para el desarrollo políticas sostenibles, de marcos aplicables a la Responsabilidad Social y Ambiental, y de la conciencia social orientada a la sostenibilidad (Capaldo, 2014). Para ello, es necesario recrear condiciones de entorno con incentivos adecuados, políticas públicas a largo plazo y generar alianzas efectivas entre los distintos actores sociales. Ello implica cambios radicales en las estructuras de gobernanza, en los marcos económicos, en los modelos de negocio y en los patrones de comportamiento de los consumidores y de la sociedad en general.

Un futuro más próspero depende del nuevo paradigma de vincular las actividades comerciales y el desarrollo, promoviendo la estabilidad social, ambiental y económica. A fin de abordar dicha problemática, teniendo presente la creciente interdependencia señalada, se reconoce igualmente importante fortalecer las políticas nacionales e internacionales y la cooperación internacional como herramienta de adaptación a las nuevas circunstancias mundiales (Romano, 2014).

Asimismo, se considera fundamental conocer las normas voluntarias sobre Reponsabilidad Social, ya que estas pueden cubrir algunas lagunas jurídicas, o bien, complementar la normativa. Todo lo anterior podría ser un resultado de la escasa valoración de los ecosistemas en su conjunto y de la falta de incorporación del principio precautorio en el ordenamiento jurídico vigente.

Finalmente, y conforme se había destacado, la Responsabilidad Social se vincula con el Derecho y comparte los mismos principios que los instrumentos internacionales sobre derechos humanos y protección ambiental. Se plantea cumplir con la normativa well as those to achieve a cleaner production, and with the promotion of environmental education, which appeared in a series of international instruments, in a voluntary guide on Social Responsibility, and in current mandatory regulations in Argentina. In this sense, we can establish that in order to favor an education that incorporates these concepts it would be convenient to modify some curricular structures and to highlight the socio-environmental dimension, the interdisciplinary approach, and the strengthening of inter-institutional relations to be able to transmit the concepts correctly.

This is based on the fact that environmental education is the only one capable of building collective awareness about the value of the environment and the need to take care of it and recover it (Mathus Escorihuela, 2011). This refers to a qualitative jump with regards to training, since it is centers on the moral dimension of the human being, that is, it implies implementation (behavior) of what is conceptually appreciated and considered valuable according to the global idea of life there is (García, 2010).

The generation of interdisciplinary knowledge turns out to be a fundamental approach and provides a solid support for the development of sustainable policies, frameworks applicable to Social and Environmental Responsibility, and for the social awareness directed at sustainability (Capaldo, 2014). For this purpose, it is necessary to recreate conditions of the environment with adequate incentives, public policies in the long term, and to generate effective alliances between the different social actors. This implies radical changes in governance structures, economic frameworks, business models, and in behavior patterns of the consumers and society at large.

A more prosperous future depends on the new paradigm of linking commercial activities and development, promoting social, environmental and economic stability. With the aim of addressing this problematic, taking into account the growing interdependence pointed out, it is recognized as equally important to strengthen the national and international policies and international cooperation as an adaptation tool to the new global circumstances (Romano, 2014).

Likewise, it is considered fundamental to understand the voluntary regulations on Social Responsibility, since these can cover some legal lapses, or else, complement the regulations. All of 
obligatoria, pero el desarrollo socialmente responsable implica involucrarse activamente con la comunidad en general sobrepasando las exigencias legales. Sin embargo, para que esto sea posible deberán existir personas formadas en la problemática socio-ambiental y que hayan sido educadas con dicha impronta preferentemente desde los niveles iniciales.

\section{Notas}

${ }^{3}$ La prestación del servicio educativo se realizará a través del sistema educativo provincial, constituido por las unidades funcionales creadas al efecto y que abarcarán los distintos niveles y modalidades de la educación.

La legislación de base del sistema educativo provincial se ajustará a los principios siguientes:

1. La educación pública de gestión oficial es gratuita en todos los niveles.

2. La educación es obligatoria en el nivel general básico.

3. El sistema educativo garantizará una calidad educativa equitativa que enfatice el acervo cultural y la protección y preservación del medio ambiente, reafirmando la identidad bonaerense.

4. El servicio educativo podrá ser prestado por otros sujetos, privados o públicos no estatales dentro del sistema educativo provincial y bajo control estatal.

* Offering the educational service will be done through the provincial educational system, constituted by the functional units created for this purpose and which will cover the different levels and modalities of education.

The basic legislation of the provincial educational system will be adjusted to the following principles:

1. Public education of official management is free at all levels.

2. Education is mandatory at the basic general level.

3. The educational system will guarantee an equitable quality in education that emphasizes the cultural heritage and the protection and preservation of the environment, reaffirming the Buenos Aires identity.

4. The educational service can be offered by other subjects, private or non-state public, within the provincial educational system and under state control.

4"La educación ambiental constituye el instrumento básico para generar en los ciudadanos valores, this could be the result of the scarce valuation of ecosystems as a whole and the lack of incorporation of the precautionary principle in the current legal system.

Finally, and as had been highlighted, Social Responsibility is linked to the Law and shares the same principles that international instruments have on human rights and environmental protection. It is suggested to comply with the mandatory regulations, although socially responsible development implies becoming actively involved with the community at large surpassing the legal demands. However, for this to be possible there should be people trained in the socio-environmental problematic and who have been educated in this, preferably since the initial levels.

- End of the English version -

comportamientos y actitudes que sean acordes con un ambiente equilibrado, propendan a la preservación de los recursos naturales y su utilización sostenible, y mejoren la calidad de vida de la población. La educación ambiental constituirá un proceso continuo y permanente, sometido a constante actualización que, como resultado de la orientación y articulación de las diversas disciplinas y experiencias educativas, deberá facilitar la percepción integral del ambiente y el desarrollo de una conciencia ambiental, Las autoridades competentes deberán coordinar con los consejos federales de Medio Ambiente (COFEMA) y de Cultura y Educación, la implementación de planes y programas en los sistemas de educación, formal y no formal. Las jurisdicciones, en función de los contenidos básicos determinados, instrumentarán los respectivos programas o currículos a través de las normas pertinentes". "Environmental education constitutes the basic instrument to generate values, behaviors and attitudes in citizens that are in accordance with a balanced environment, tend to the preservation of natural resources, and their sustainable use, and improve the life quality of the population. Environmental education will constitute a continuous and permanent process, subject to constant updating that, as a result of the orientation and articulation of various disciplines and educational experiences ought to facilitate the integral perception of the environment and the development of an environmental consciousness. The competent authorities 
should coordinate with the federal Environment, Culture and Education Councils (COFEMA), the implementation of plans and programs in the formal and informal education systems. The jurisdictions, in function of the basic contents determined, will implement the respective programs or curricula through the pertinent regulations".

${ }^{5}$ El Poder Ejecutivo Provincial y los municipios garantizarán, en la ejecución de las Políticas de gobierno la observancia de los derechos reconocidos en el artículo $2^{\circ}$, así como también de los principios de política ambiental que a continuación se enumeran: Inciso e): El Estado Provincial promoverá la formación de individuos responsables y solidarios con el medio ambiente. A tal efecto la educación ambiental debe incluirse en todos los niveles del sistema educativo, bajo pautas orientadas a la definición y búsqueda de una mejor calidad de vida. * The Provincial Executive Power and the municipalities will guarantee, in the execution of government policies the observance of rights recognized in article 2 , as well as those of environmental policy that are listed next: Topic e): The Provincial State will promote the training of individuals who are responsible and solidary with the environment. For this purpose, environmental education must be included at all levels the educational system, under standards directed towards the definition and search of a better quality of life.

${ }^{6} \mathrm{~A}$ partir del año 2015 este organismo público ha sido reemplazado por el Ministerio de Agroindustria, para mayor información es posible consultar en la siguiente página web: http://www.agroindustria. gob.ar/sitio/. Since 2015, this public organization has been replaced by the Agroindustry Ministry; for more information it is possible to consult the following webpage: http://www.agroindustria.gob.ar/sitio/. ${ }^{7}$ Para mayor información es posible consultar en el siguiente link: http://pactoglobal.org.ar/. * For further information it is possible to consult the following link: http://pactoglobal.org.ar/.

\section{Literatura Citada}

Capaldo, Griselda. 2014. La interdisciplina y la transdisciplina como estrategias para la erradicación de conductas anómicas y la enseńanza del Derecho en torno a la gestión del agua. In: Academia, Año 12, No 23.

Carrizosa Umańa, Julio. 2007. Ciencias ambientales una nueva área del conocimiento, Compilador: Orlando Sáenz, Red Colombiana de Formación Ambiental, RCFA, En línea, disponible en file://C:/Users/Clara/Downloads/Libro_Cien-
cias_Ambientales.pdf (Visitado el 5 de mayo de 2017).

Consejo Profesional de Ingeniería Agronómica, Desafíos del ejercicio profesional para aportar a las sustentabilidad. En línea, disponible en www.cpia.org.ar/agropost/201410/notaopinion1.html (visitado el 5 de mayo de 2017).

Gally, Teresa, y María Victoria Giachino. 2014. Aplicación de los principios de sustentabilidad en fitopatología, herramientas que ayudan a su implementación. In: Memorias del 3o Congreso Argentino de Fitopatología, San Miguel de Tucumán, Argentina.

García Saura, Pilar Juana. 2010. Por una lesgilación comprometida con la sustentabilidad turística. Información, formación y educación ambiental e investigación, factores a considerar. In: Revista Observatorio Medioambiental, Volumen 13.

Giuffré, Lidia. 2004. Los Objetivos de Desarrollo del Milenio y la educación ambiental. In: Revista de la Facultad de Agronomía, Num. 24 (2). En línea, disponible en http://www. bvsde.paho.org/bvsacd/cd27/giuffre.pdf (visitado el 5 de mayo de 2017).

ISO (International Standard Organization). 2010. Guidance on Social Responsibility ISO 26.000, 2010.

Laterra, Pedro, Esteban Jobbágy, y José Paruelo. 2011. Valoración de los servicios ecosistémicos. Conceptos, herramientas y aplicaciones para el ordenamiento territorial (2011), Argentina, Ediciones INTA.

Martinez Huerta, José Féliz (s/f). Fundamentos de la Educación Ambiental disponible en https://www.unescoetxea.org/ext/ manual/html/fundamentos.html (visitado el 5 de mayo de 2017).

Mathus Escorihuela, Miguel. 2011. Gobernanza y manejo sustentable del agua - Governance and sustainable management wáter. En: Griselda Capaldo (coord). Sinergias ambientales e instituciones de gestión. Argentina. Editorial Mnemosune. pp: 325-337.

Minaverry, Clara. 2011. Fortalezas y debilidades de la legislación sobre protección de bosques nativos, y su vinculación con la normativa sobre aguas en la Argentina. In: Memorias del Primer Encuentro Internacional de Derecho Forestal Ambiental del Cono Sur, Asunción Paraguay, 7 al 10 de Septiembre de 2011.

Minaverry, Clara. 2013. La protección legal del agua potable en Argentina y su inclusión en la agenda internacional. In: Memorias del XI Congreso Nacional de Ciencia Política, organizado por la Sociedad Argentina de Análisis Político y la Universidad Nacional de Entre Ríos, Paraná, 17 al 20 de julio de 2013.

Minaverry, Clara, y Teresa Gally. 2014. Algunas consideraciones sobre la sustentabilidad en la agricultura argentina. Herramientas para el cumplimiento de la normativa ambiental. In: Revista Avances en Investigación Agropecuaria, Segunda época, Volumen 18, Num. 2, mayo-agosto, Universidad de Colima, México.

Minaverry, Clara, y Teresa Gally. 2013. Las normas voluntarias SA 8000 e ISO 26.000 sobre responsabilidad social y su importancia ante la debilidad del Derecho. In: Revista ArsBoni et Aequi, Año 9 Num. 2, Facultad de Derecho y Comunicación Social, Universidad O’Higgins, Chile, ISSN 07192568.

Minaverry, Clara, y Teresa Gally, y Francisco Pantuso. 2016. La guía ISO 26.000 y su importancia en la protección de la 
biodiversidad en Argentina, In: Revista Sociedades rurales, producción y medio ambiente, Volumen $16, \mathrm{~N}^{\circ} 31$, ISSN: 2007-7556, Universidad Autónoma de Metropolitana, Unidad Xochimilco, México.

Minaverry, Clara; Jorge López, y Teresa Gally. 2012. Análisis comparativo entre la norma SA 8000 y la norma ISO 26.000:2010 en la actualidad. In: Resúmenes II Jornadas de Enseñanza de la Ingeniería JEIN 2012, y versión extendida del artículo, San Nicolás, Provincia de Buenos Aires, Argentina, 2 y 3 de Agosto de 2012.

Minaverry, Clara, y Adriana Martínez. 2016. La defensa de los derechos ambientales y de la naturaleza por las mujeres y los Objetivos de Desarrollo Sostenible en América Latina. Perspectivas, realidades y reflexiones. In: Memorias del IV Encuentro internacional de investigación de género, Universidad Nacional de Luján, 12 al 14 de mayo de 2016.
Ministerio de Agricultura, Ganadería y Pesca de la Nación. 2010. Plan Estratégico Agroalimentario y Agroindustrial Participativo y Federal 2010-2020. En línea, disponible en www. minagri.gob.ar/site/areas/PEA2/index.php (visitado el 25 de diciembre de 2014).

Nelliyat, Prakash, and N. Ambujan. 2011. Need for Integrated Water and Land Resources Management. Approach for Sustainable Ecosystem and Water Security in Third World Cities. In: Abstract Volume World Water Week in Stockholm, Stockholm International Water Institute (SIWI). Editora: Ingrid Stangberg, 21-27 de Agosto de 2011.

Pigretti, Eduardo. 2000. Derecho Ambiental, Editorial Depalma, Buenos Aires.

Romano, Carolina. 2014. Sustentabilidad y Derechos Humanos en la Argentina. In: Memorias de FLACSO-ISA Joint International Conference Buenos Aires Global and regional powers in a changing world, Facultad de Ciencias Económicas, Universidad de Buenos Aires, 23 al 25 de julio de 2014. 